\title{
FUNGISTATIC ACTIVITY OF ESSENTIAL OILS EXTRACTED FROM Peumus boldus Mol., Laureliopsis philippiana (Looser) Schodde AND Laurelia sempervirens (Ruiz \& Pav.) Tul. (CHILEAN MONIMIACEAE)
}

\author{
Magalis Bittner $^{1 *}$, Milenko A. Aguilera ${ }^{1}$, Víctor Hernández ${ }^{1}$, Cecilia Arbert ${ }^{1}$, José Becerra ${ }^{1}$, \\ and María E. Casanueva ${ }^{1}$
}

\begin{abstract}
Components of essential oils from the Chilean Monimiaceae, boldo (Peumus boldus Mol.), tepa (Laureliopsis philippiana (Looser) Schodde), and laurel (Laurelia sempervirens (Ruiz \& Pav.) Tul.) were determined using Gas Chromatography- Mass Spectrometry (GCMS) and fungistatic activity of the essential oils was tested against Rhizoctonia solani Kühn (Donk), Pythium irregulare Buisman, Ceratocystis pilifera (Fr.) C. Moreau, Phragmidium violaceum (Schultz) G. Winter, and Fusarium oxysporum Schltdl. The essential oils of the Monimiaceae species shared some common components; all three had the 3-carene, $\alpha$-phellandrene, and $\alpha$-pinene terpenes. L. philippiana and $L$. sempervirens also had safrole. The main components were ascaridol in P. boldus oil, 3-carene in L. philippiana, and safrole in L. sempervirens. The essential oil from L. sempervirens showed the highest fungistatic activity with significant differences in dose as well as exposure. P. violaceum was the most sensitive strain and $P$. irregulare the most resistant of all the essential oils (P. boldus extract affected growth by only 19\%). Therefore, essential oils from these three plants could be used to control the fungal strains studied.
\end{abstract}

Key words: Chilean native trees, chemical components, natural fungistatic activity, in vitro analysis.

\section{INTRODUCTION}

Chemical and biological studies are useful to understand and appreciate biodiversity. In general, isolating, identifying, and determining structures of new metabolites are fundamental to reveal their chemical potential, a first step to use, conserve, and protect them (Castillo, 1992). According to Niemeyer (1995), about 5\% of all 5971 known species of Chilean flora (Marticorena, 1990) have been chemically studied.

Moreover, there is great interest to replace synthetic xenobiotics with similar acting natural compounds. It is important to determine secondary metabolites with fungicidal or fungistatic activity, since they allow the use of natural origin compounds that are generally speciesspecific, have low environmental persistence, and are biodegradable.

In Chile, chemical and biological studies of members of the Monimiacea family: boldo (Peumus boldus Mol.),

\footnotetext{
${ }^{1}$ Universidad de Concepción, Facultad de Ciencias Naturales y Oceanográficas, Casilla 160-C, Concepción, Chile.

*Corresponding author (mbittner@udec.cl).

Received: 19 November 2007.

Accepted: 28 July 2008.
}

tepa (Laureliopsis philippiana (Looser) Schodde), and laurel (Laurelia sempervirens (Ruiz \& Pav.) Tul.) (Rodríguez and Quezada, 2001), have attempted to determine aporphinic and bisbenzylisoquinolinic types of alkaloid compounds (Hoffmann et al., 1992; Vogel et al., 1999; Montes et al., 2001). Studies of L. philippiana and L. sempervirens revealed isoquinolinic alkaloids derived from aporphine, noraporphine, and bisbenzylisoquinolinictype alkaloid compounds (Speisky and Cassels, 1994). Chemical studies of these plants have been mostly aimed at their use in popular medicine where $\alpha$-pinene, $\beta$ pinene, $\mathrm{p}$-cimole, linalole, limonene, ascaridole, benzyl benzoate, benzaldehyde, camphene, 1.8-cineole, $\alpha$ hexylcinnamaldehyde, p-cymene, eugenol methyl ether, and safrole have been identified in their essential oils. The chemistry of $P$. boldus has been studied more and is used in popular medicine; its alkaloids and essential oils have been isolated with ascaridole as the main component (Zin and Weiss, 1998; Vogel et al., 1999; Schrickel and Bittner, 2001). The most important component of the essential oil from L. sempervirens leaves is safrole (Montes et al., 2001). Although information is lacking on the chemical and biological activity of L. philippiana (Arbert, 2002), it was found to contain asimilobine, anonaine, and norcoridine (Urzúa and Cassels, 1982). 
Bittner et al. (2008) previously tested the effect of essential oils from Gomortega keule (Molina) I. M. Johnst., Laurelia sempervirens, Origanum vulgare L., Eucalyptus globulus Labill., and Thymus vulgaris L. on the Sitophilus zeamais and Acanthoscelides obtectus (Coleoptera) granary weevils obtaining promissory results that suggest their use in grain storage pest control.

Ceratocystis pilifera is found in Chile on numerous pine species, especially Pinus radiata D. Don, as well as on the surface of sawed lumber causing blue stain (bluing) (Parra et al., 2001). Fusarium oxysporum frequently causes problems in forest nurseries by affecting seeds and/or seedlingsand causing "damping off" (Alvarez and Nishijima, 1987) where necrotic rings correspond to collapsed parenchymatic cells. This results from the secretion of characteristic toxins of the Fusarium genus species and its capacity to decompose celullose. A formae speciale (f.sp.) that explains a special disease in Pinus species does not yet exist in spite of the economic importance of these diseases in Chilean nurseries (Webster and Weber, 2007). Rhizoctonia solani and representatives of the Pythium genus (generally controlled by fungicides) also cause "damping off" in seedlings (Butin and Peredo, 1986). Phragmidium violaceum is a compulsory parasite on several Rubus species and causes rust (Oehrens and González, 1974).

Alternative low cost, effective, and species-specific control methods should be found that do not leave permanent toxic residues in the environment. Previous studies of essential oils from aromatic plants such as Ocimum canum Sims, Citrus medica (L.) (Dubey et al., 1983), Pimpinella anisum (L.) (Shukla y Tripathi, 1987), Cinnamomum camphora (L.) J. Presl (Mishra et al., 1991), Cymbopogon citratus (DC.) Stapf (Mishra y Dubey, 1994), and Chenopodium ambrosioides L. (Mishra et al., 2002) have demonstrated their strong fungicidal activity.

Becerra et al. (2002) and Solis et al. (2004) have shown antifungal activity of natural terpenes isolated from extractives of Chilean gymnosperm species from the Podocarpaceae and Cupressacea families, respectively.

The objective of this study was to determine chemical components and in vitro fungistatic potential of essential oils from threenative Chilean plantspecies(Peumus boldus, Laureliopsis philippiana, and Laurelia sempervirens) on important pathogens such as Rhizoctonia solani, Pythium irregulare, Ceratocystis pilifera, Phragmidium violaceum, and Fusarium oxysporum.

\section{MATERIALS AND METHODS}

\section{Biological material}

Fresh material was collected from L. philippiana, $L$. sempervirens, and P. boldus (Monimiaceae) on 2 June,
2003 in the Huachi sector of Santa Bárbara (37³1' S, $71^{\circ} 51^{\prime}$ W), Bío-Bío Region, Chile. Leaves were placed in plastic bags, labelled to indicate species, site, date, and collector after which they were taken to the Natural Products Chemical Laboratory of the Facultad de Ciencias Naturales y Oceanográficas, Universidad de Concepción. Identification was confirmed by comparing reference material for each species with material from the herbarium of the Universidad de Concepción.

The strains of $C$. pilifera, $F$. oxysporum, and $P$. violaceum were isolated from pine species in nurseries of the Bío-Bío Region damaged by these organisms and were classified by Dr. R. Weber from the Fruit Research Station (OVB) in Jork, Germany. The $R$. solani and $P$. irregulare strains were kindly donated by Dr. R. Weber. All the strains are maintained in permanent cultures in the Natural Products Chemical Laboratory.

\section{Extraction of essential oils}

Leaves from each species under study were snipped and essences were extracted by hydrodistillation as established by Montes et al. (2001) and Céspedes et al. (2002).

\section{Identification of essential oils}

Water was eliminated from the essential oils by treating them with sodium sulfate anhydrous. The composition of the essential oils was determined with a Gas Chromatograph Mass Spectrometer(GCMS) (Hewlett Packard, series II 5890, Avondale, Arizona, USA), using an HP-5MS Capillary Column (5\%-diphenyl-95\%dimethylsiloxane), ID (internal diameter) $0.25 \mathrm{~mm}$, length $30 \mathrm{~m}$, df (film thickness) $0.25 \mu \mathrm{m}$. Relative percentages of the essential oil components were obtained for each species by using helium as a mobile phase with a mass detector (Hewlett Packard, Mod 5972 series, Avondale, Arizona, USA).

\section{Evaluation of fungistatic activity}

Essential oils were directly assayed to each fungus with $30 \%$ and $50 \%$ dilution and undiluted (100\%). A control was used for each case by not exposing the fungus to any extract.

Qualitativeandquantitativeassays offungicidalactivity were done using Woodward and De Groot 1999 by adding a $1 \mathrm{~cm}$ diameter of each fungal growth (three replicates) in the center of a Petri dish containing culture medium with agar, sacarose, malt and yeast extracts (Merck ${ }^{\mathrm{TM}}$ ), or other nutrients according to the requirements of each fungus (NCCLS, 2000). Paper filter discs (Whatman $\mathrm{Nr}$ $3,6 \mathrm{~mm}$ diameter) impregnated with increasing dilutions $(30,50$, and $100 \%)$ of different extracts obtained from the three species were placed around the fungi. These were 
then incubated at $24^{\circ} \mathrm{C}$ (per requirements of each species) (Woodward and De Groot, 1999) for $21 \mathrm{~d}$ and the diameter of their inhibition halos was measured alternately every $3^{\text {rd }}$ and $4^{\text {th }} \mathrm{d}$ (Woodward and De Groot, 1999). These activities were considered to be positive when inhibitory action of the fungal growth was observed and negative when it was not. The percentage of growth inhibition was calculated by measuring the control halo (untreated fungi), which was set at $100 \%$, and comparing it to the growth of the treated fungi. The percentage was calculated with the slope drawn for the measurements taken every $3^{\text {rd }}$ and $4^{\text {th }}$ $\mathrm{d}(3,7,10,14,17$ and $21 \mathrm{~d})$ and comparing them with the control halo.

\section{Data analysis}

In order to determine significant differences in toxicity among treatments, a two-way ANOVA was carried out using the Statistica 6.0 software package (Statsoft, 2008). The results showed significant differences at $\mathrm{p}<0.01$ according to the Tukey test for time and the Dunnett test for dose.

\section{RESULTS}

The gas-mass analysis of the oils showed 18 main derived components, 13 in P. boldus, 8 in L. philippiana, and 6 in L. sempervirens. The three Monimiaceae species had the 3-carene, $\alpha$-phellandrene, and $\alpha$-pinene terpenes. The main components were ascaridole in P. boldus oil
(34.80\%), 3-carene in L. philippiana oil (53.81\%), and safrol in L. sempervirens oil (69.30\%) (Table 1).

The results of the fungistatic activity of the three concentrations of essential oils from the three species studied are presented in Table 2.

The growth rate of $P$. violaceum was slowed $62 \%$ by the essential oil from L. philippiana (undiluted), 61\% (50\% dilution), and $60 \%$ (30\% dilution). In F. oxysporum, these rates were $59.6 \%$ (undiluted), 59.2\% (50\% dilution), and $58.2 \%$ (30\% dilution). In $R$. solani and C. pilifera growth rates were slowed $51 \%$ (undiluted), $46.2 \%$ (50\% dilution), $42 \%$ (30\% dilution) and $48.5 \%$ (undiluted), $48.4 \%$ (50\% dilution), $47 \%$ (30\% dilution) respectively (Table 2).

According to ANOVA, the effects of different doses and times of exposure were significant at $\mathrm{p}<0.01$ (Tables 2 and 3). Of the three plants studied, L. philipiana showed significant differences in relation to time and dose treatments, in contrast to other plant differences that were mainly due to exposure times. Laureliopsis philipiana showed the highest growth inhibition activity of tested fungi, being more effective in $P$. violaceum with $62 \%$ inhibition using undiluted essential oils, $61 \%$ inhibition (50\% diluted) and 60\% inhibition $(30 \%$ diluted). For F. oxysporum, the levels of inhibition were $59.6 \%$ (undiluted), $59.2 \%$ (50\% diluted), and 58.2\% (30\% diluted). Differences were significant in both fungi for time and dose. There was no significant difference in exposure time for L. philipiana, which showed the same

Table 1. Main components of the essential oils from Peumus boldus, Laureliopsis philippiana, and Laurelia sempervirens.

\begin{tabular}{|c|c|c|c|}
\hline Compound & Peumus boldus & Laureliopsis philippiana & Laurelia sempervirens \\
\hline & & $-\%$ & \\
\hline Ascaridole & 34.80 & - & - \\
\hline 3-Carene & 1.81 & 53.81 & 1.97 \\
\hline$\alpha$-Phellandrene & 1.01 & 2.95 & 0.92 \\
\hline$\beta$-Phellandrene & 5.43 & - & 1.98 \\
\hline 1,2-Dimethoxy-4-(2-propenyl)-phenol & - & 10.58 & - \\
\hline Safrole & - & 2.33 & 69.30 \\
\hline$\alpha \alpha-1-M e t h y l-3$-cyclohexane & - & 5.86 & \\
\hline$\alpha$-Pinene & 3.19 & 2.30 & 0.39 \\
\hline$\beta$-Pinene & 1.02 & - & - \\
\hline Limonene & 16.10 & - & - \\
\hline Eucalyptol (cineole) & 11.95 & 14.76 & - \\
\hline$\alpha$-Terpineol & 8.90 & - & - \\
\hline$\beta$-Myrcene & 0.37 & - & - \\
\hline p-Cymol & 7.85 & - & - \\
\hline Linalool & 1.03 & - & - \\
\hline Nerolidol & 4.95 & - & - \\
\hline$\alpha$-1-Methyl-3-cyclohexadiene & - & 5.14 & - \\
\hline 1-Methyl-4-1-methyl ethyl cyclohexane & - & - & 18.55 \\
\hline Other components & 1.59 & 2.27 & 6.89 \\
\hline
\end{tabular}


fungus growth inhibition throughout the treatment whereas there were significant differences in exposure time in $L$. sempervirens and $P$. boldus, on average between 7 and 10 $\mathrm{d}$ when the greatest inhibition occurred in the tested fungi (Table 2). It should be noted that $P$. irregulare was the fungus that showed the greatest resistance to treatment with essential oils of the three plants.

\section{DISCUSSION}

Of the main terpenes found in the essential oils of P. boldus, L. philippiana and L. sempervirens, the components ascaridole, 3-carene, and $\alpha$-phellandrene were previously described for P. boldus (Gupta, 1995; Schrickel and Bittner, 2001; Montes et al., 2001) and safrole for L. sempervirens (Montes et al., 2001).

The results of this study concur with the research cited above, but also revealed safrole in L. philippiana and1,2dimethoxy-4-(2-propenyl)-phenol was found exclusively in this species. Eucalyptol was ascertained in P. boldus and L. philippiana essential oils. Finally, L. philippiana revealed the presence of $\alpha$-1-methyl-3-cyclohexadiene, previously described for Persea lingue (Ruiz \& Pav.) and Nees, a member of the Lauraceae family, which is close to the Monimiaceae family (Marticorena and Rodríguez, 2001).

Table 2. Inhibition of growth rates (\%) of fungi exposed to three concentrations of the essential oils extracted from Peumus boldus, Laureliopsis philippiana, and Laurelia sempervirens.

\begin{tabular}{|c|c|c|c|c|c|c|c|c|c|c|}
\hline \multirow[b]{3}{*}{ Species } & \multirow[b]{3}{*}{ Control } & \multicolumn{3}{|c|}{ P. boldus } & \multirow{2}{*}{\multicolumn{3}{|c|}{$\begin{array}{c}\text { L. philippiana } \\
\text { Concentration \% }\end{array}$}} & \multicolumn{3}{|c|}{ L. sempervirens } \\
\hline & & & & & & & & & & \\
\hline & & 100 & 50 & 30 & 100 & 50 & 30 & 100 & $\mathbf{5 0}$ & 30 \\
\hline Ceratocystis pilifera & 0.0 & 0.0 & 0.0 & 0.0 & 48.5 & 48.4 & 47.0 & 28.4 & 25.2 & 25.0 \\
\hline Phragmidium violaceum & 0.0 & 45.0 & 45.0 & 27.4 & 62.0 & 61.0 & 60.0 & 36.0 & 13.0 & 11.0 \\
\hline Fusarium oxysporum & 0.0 & 25.2 & 24.4 & 24.0 & 59.6 & 59.2 & 58.2 & 3.5 & 3.0 & 2.6 \\
\hline Pythium irregulare & 0.0 & 19.0 & 0.0 & 0.0 & 9.0 & 8.0 & 7.0 & 6.0 & 0.0 & 0.0 \\
\hline Rhizoctonia solani & 0.0 & 26.0 & 23.3 & 21.0 & 51.0 & 46.2 & 42.0 & 6.10 & 6.0 & 5.2 \\
\hline
\end{tabular}

Table 3. Results of ANOVA for essential oil dose and exposure time on Fusarium oxysporum, Phragmidium violaceum, Ceratocystis pilifera, Rhizoctonia solani and Pythium irregulare.

\begin{tabular}{|c|c|c|c|c|c|c|c|}
\hline & \multirow[b]{2}{*}{ DF } & \multicolumn{2}{|c|}{ Laureliopsis philippiana } & \multicolumn{2}{|c|}{ Laurelia sempervirens } & \multicolumn{2}{|c|}{ Peumus boldus } \\
\hline & & Mean Square & $\mathbf{F}$ & Mean Square & $\mathbf{F}$ & Mean Square & $\mathbf{F}$ \\
\hline Time & 5 & 4032.57 & $22.76^{*}$ & 6837.57 & $2032.74 *$ & 5560.85 & $53141^{*}$ \\
\hline Dose & 3 & 2494.68 & $14.08^{*}$ & 3.36 & 1.00 & 25.41 & 2.43 \\
\hline Dose $\mathrm{x}$ Time & 15 & 177.18 & & 3.36 & & 10.46 & \\
\hline Time & 5 & 3910.39 & $49.65 *$ & 6225.58 & $116.20 *$ & 6225.58 & $116.20 *$ \\
\hline Dose & 3 & 1362.93 & $17.31 *$ & 420.66 & 7.85 & 420.66 & 7.85 \\
\hline Dose x Time & 15 & 78.75 & & 53.58 & & 53.58 & \\
\hline Time & 5 & 5272.15 & $32.58 *$ & 5863.19 & $108.11^{*}$ & 4537.50 & $843.10^{*}$ \\
\hline Dose & 3 & 420.90 & 2.60 & 120.90 & 2.23 & 5.38 & 1.00 \\
\hline Dose $\mathrm{x}$ Time & 15 & 161.84 & & 54.23 & & 5.38 & \\
\hline Time & 5 & 3925.73 & $87.04 *$ & 6854.65 & $109.56^{*}$ & 5451.00 & $117.78^{*}$ \\
\hline Dose & 3 & 1073.18 & $23.79 *$ & 137.57 & 2.20 & 212.74 & 4.60 \\
\hline Dose $\mathrm{x}$ Time & 15 & 45.10 & & 62.57 & & 46.28 & \\
\hline Time & 5 & 4251.72 & $584.48 *$ & 4316.63 & $1398.81 *$ & 4451.63 & $622.74 *$ \\
\hline Dose & 3 & 17.01 & 2.34 & 6.84 & 2.22 & 25.07 & 3.51 \\
\hline Dose $\mathrm{x}$ Time & 15 & 7.27 & & 3.09 & & 7.15 & \\
\hline
\end{tabular}

* Values differ significantly at $\mathrm{p}<0.01 . \quad$ DF: degrees of freedom. $\quad$ F: Statistic F. 
Table 4. Results of multiple comparisons with means and standard error (SE) for exposure time and dilution of essential oil o Fusarium oxysporum, Phragmidium violaceum, Ceratocystis pilifera, Rhizoctonia solani, and Pythium irregulare.

\begin{tabular}{|c|c|c|c|c|c|c|c|c|}
\hline & & \multirow[b]{2}{*}{$\mathbf{n}$} & \multicolumn{2}{|c|}{ Laureliopsis philippiana } & \multicolumn{2}{|c|}{ Laurelia sempervirens } & \multicolumn{2}{|c|}{ Peumus boldus } \\
\hline & & & Mean & SE & Mean & SE & Mean & SE \\
\hline \multicolumn{9}{|c|}{ Fusarium oxysporum } \\
\hline \multirow{6}{*}{ Time, d } & 3 & 4 & 1.25 & 12.50 & 0.00 & 0.00 & $5.31 *$ & 0.31 \\
\hline & 7 & 4 & 20.00 & 116.70 & $48.44 *$ & 22.46 & $54.06^{*}$ & 0.94 \\
\hline & 10 & 4 & 44.06 & 165.63 & $93.75^{*}$ & 0.00 & $82.81 *$ & 38.65 \\
\hline & 14 & 4 & 49.38 & 168.75 & $100.00 *$ & 0.00 & 94.38 & 18.75 \\
\hline & 17 & 4 & 65.00 & 117.70 & 100.00 & 0.00 & 100.00 & 0.00 \\
\hline & 21 & 4 & 90.63 & 31.25 & 100.00 & 0.00 & 100.00 & 0.00 \\
\hline \multirow{4}{*}{ Dilution, $\%$} & 100 & 6 & 34.17 & 129.37 & 73.13 & 170.59 & 70.83 & 151.85 \\
\hline & 50 & 6 & 34.79 & 129.60 & 73.33 & 169.92 & 71.88 & 150.68 \\
\hline & 30 & 6 & 35.63 & 132.12 & 73.54 & 169.26 & 72.71 & 149.53 \\
\hline & Control & 6 & 75.63 & 158.37 & 74.79 & 165.84 & 75.63 & 158.37 \\
\hline
\end{tabular}

Phragmidium violaceum

\section{Time, d 3}

10

$$
\begin{array}{r}
50 \\
30
\end{array}
$$

$$
\text { Control }
$$

Ceratocystis pilifera

Time, d

Rhizoctonia solani

$\begin{array}{lr}\text { Time, d } & 3 \\ & 7 \\ & 10 \\ & 14 \\ 17 \\ 21 \\ \text { Dose, \% } & 100 \\ & 50 \\ & 30\end{array}$

Control

Pythium irregulare

Time, d

$\begin{array}{lr}\text { Time, d } & 3 \\ & 7 \\ 10 \\ 14 \\ 17 \\ 21 \\ \text { Dilution, \% } & 100 \\ & 50 \\ & 30 \\ & \text { Control }\end{array}$

17
17

Dilution, \% $\quad 100$

3.73
36.57
61.19
76.49
79.10
84.33
47.02
50.00
51.24
79.35

0.75
108.06
134.74
79.07
70.01
53.64
119.45
123.91
123.54
155.66

1.28
$31.09^{*}$
$67.31^{*}$
$91.67^{*}$
94.23
96.80
55.34
60.90
63.46
75.21

12.82

95.71

66.31

43.63

34.92

19.23

158.01

165.87

173.46

154.51

$$
\begin{array}{r}
24.67 \\
159.75 \\
67.99 \\
0.00 \\
0.00 \\
0.00 \\
164.82 \\
160.01 \\
155.85 \\
137.50
\end{array}
$$

100.00

68.13

69.38

71.88

86.25

1.25
$38.44^{*}$
52.50
71.88
75.94
86.88
44.58
48.33
50.83
74.17

12.50
72.42
91.00
94.30
82.82
53.40
111.56
121.01
131.13
152.98

$3.75^{*}$

$30.94 *$

$67.50^{*}$

$100.00^{*}$

100.00

100.00

64.17

64.38

65.42

74.17
43.75
88.59
0.63
0.00
0.00
0.00
165.55
164.62
164.37
137.50

0.72

97.28

41.77

0.00

0.00

0.00

178.96

178.94

172.98

152.98

$15.63^{*}$
$75.31^{*}$
$88.75^{*}$
$96.56^{*}$
100.00
100.00
77.08
79.17
80.42
80.83

$\begin{array}{rc}11.97 & 17.50^{*} \\ 24.14 & 82.50^{*} \\ 12.50 & 98.44^{*} \\ 21.27 & 100.00 \\ 0.00 & 100.00 \\ 0.00 & 100.00 \\ 132.71 & 81.88 \\ 129.21 & 83.75 \\ 131.25 & 84.17 \\ 140.34 & 82.50\end{array}$

$5.97 *$
$52.24 *$
$77.99 *$
82.46
90.30
94.78
61.44
62.69
65.92
79.10

0.00

55.51

74.72

60.13

33.65

21.54

128.19

131.87

136.60

154.97

$\begin{array}{rr}17.50^{*} & 28.41 \\ 100.00^{*} & 0.00 \\ 100.00 & 0.00 \\ 100.00 & 0.00 \\ 100.00 & 0.00 \\ 100.00 & 0.00 \\ 85.42 & 145.83 \\ 85.63 & 143.75 \\ 86.46 & 135.42 \\ 87.50 & 125.00\end{array}$

$$
\begin{array}{r}
5.00^{*} \\
43.13^{*} \\
63.44^{*} \\
81.88 \\
100.00 \\
100.00 \\
60.63 \\
62.92 \\
64.58 \\
74.17
\end{array}
$$

0.00

56.25

60.25

65.65

0.00

0.00

151.72

151.72

154.03

152.98

*Values differ significantly according to Tukey for time and Dunnett for dose $(\mathrm{p}<0.01)$.

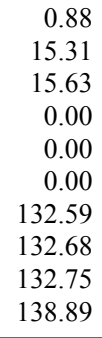
$15.63 *$
$85.63 *$
$95.31 *$
100.00
100.00
100.00
80.21
82.71
82.92
85.21

29.09

18.75

17.95

0.00

0.00

0.00

144.06

139.36

137.30

124.60 
The 3-carene, $\alpha$-phellandrene, and $\alpha$-pinene terpenes were present in the three essential oils. Although this can be explained by the fact that the species all belong to the same family (Monimiaceae), they nonetheless showed some specificity in some main components as well as others that were found in lesser concentrations.

Each of the species studied had a main component, ascaridole (34.80\%) in P. boldus, safrole (69.30\%) in $L$. sempervirens, and 3-carene (53.81\%) in L. philippiana. The greatest concentrations were found in these components, and they were thought to be responsible for the responses obtained in the biological activity assays.

Overall,the greatest growth inhibition was produced by the essential oil from L. philippiana at all doses and for all species of fungi tested. The exception was $P$. irregulare, which exhibited an average inhibition of about $50 \%$ in the strains of fungi treated. The 1,2-dimethoxy4-(2-propenyl)-phenol compound, known to be one of recognized toxic activity, was found only in L. philippiana and could be attributed to fungistatic activity (Pérez and Ubera, 2006). However, we believe that given the chemical composition of the essential oils of the species tested, this activity would be a result of a synergetic effect between the presence of phenolic compounds and those characterized as terpenes.

On the other hand, essential oil from P. boldus presented an activity inhibition that did not exceed 30\% on the average, even though it had a greater diversity in its terpene composition, but no 1,2-dimethoxy-4-(2propenyl)-phenol, which could be responsible for the increased fungistatic activity measured.

It would also be interesting to study the effect of the essential oil and crude extract of these plants on medically important fungi in order to develop new anti-fungal or fungistatic agents for preventive treatment of serious fungal disease infections in animals and human beings.

\section{CONCLUSIONS}

The analysis of all the essential oils of the three studied species revealed the following main components: ascaridole, 3 -carene, $\alpha$-phellandrene, $\beta$-phellandrene, 1,2dimethoxy-4-(2-propenyl)-phenol, safrole, $\alpha \alpha-1$ methyl3 -cyclohexane, $\alpha$-pinene, $\beta$-pinene, limonene, eucalyptol, $\alpha$-terpineol, $\beta$-myrcene, p-cymol, linalool, nerolidol, 1methyl-4-(1-methylethyl)-cyclohexene, as well as others that were found in lower concentrations.

All the dilutions of the Laureliopsis philippiana essential oil reduced growth rates around $50 \%$ in all the fungi species studied, except for Pythium irregulare which had an inhibition rate lower than $10 \%$ with the different dilutions used.
The essential oil from Laurelia sempervirens showed the lowest biological activity in all the tests.

Finally, considering the results obtained in this study, it can be concluded that the essential oils from Laureliopsis philippiana and Peumus boldus showed the best fungistatic activity. This will benefit humans in the production of specific and environmentally friendly pesticide compounds.

\section{ACKNOWLEDGEMENTS}

This study was financed by DIUC project No. 204.111.039-1.0, Universidad de Concepción, Chile, and CONICYT ACT 38.

\section{RESUMEN}

Actividad fungistática de extractos de aceites esenciales de Peumus boldus Mol., Laureliopsis philippiana (Looser) Schodde y Laurelia sempervirens (Ruiz \& Pav.) Tul. (Monimiaceae chilenas). Se determinaron los compuestos de aceites esenciales de Monimiaceae chilenas, boldo (Peumus boldus Mol.), tepa (Laureliopsis philippiana (Looser) Schodde), y laurel (Laurelia sempervirens (Ruiz \& Pav.) Tul.) a través de cromatografía de gas con espectrometría de masas (CGEM) y se midió la actividad fungistática de los aceites sobre los hongos Rhizoctonia solani Kühn (Donk), Pythium irregulare Buisman, Ceratocystis pilifera (Fr.) C. Moreau, Phragmidium violaceum (Schultz) Winter y Fusarium oxysporum Schltdl. Los aceites esenciales de las especies de Monimiaceae tienen algunos compuestos en común; en las especies estudiadas se encontró que todos tenían los terpenos 3 -careno, $\alpha$-felandreno, y $\alpha$ pineno. L. philippiana y L. sempervirens además tienen safrol. En cambio, ascaridol fue el principal compuesto en el aceite de $P$. boldus, 3-careno en L. philippiana y safrol en $L$. sempervirens. El aceite esencial de L. sempervirens presentó la mejor actividad fungistática contra las cepas tratadas, con diferencias significativas tanto en dosis como en tiempo de exposición. P. violaceum fue la cepa más sensible a los aceites esenciales y $P$. irregulare la más resistente (el extracto de $P$. boldus detuvo el crecimiento sólo un 19\%). Por lo tanto, los aceites esenciales de todos estos árboles podrían ser usados como controladores de las cepas de hongos estudiadas.

Palabras clave: árboles nativos chilenos, compuestos químicos, actividad fungistática natural, análisis in vitro. 


\section{LITERATURE CITED}

Alvarez, A.M., and W.T. Nishijima. 1987. Postharvest diseases on papaya. Plant Dis. 71(8):681-686.

Arbert, C. 2002. Estudio químico y actividad biológica de la especie arbórea Laureliopsis philippiana (Looser) Schodde, nativa de Chile, perteneciente a la familia Monimiaceae. 58 p. Unidad de Investigación Licenciatura en Biología, Universidad de Concepción, Concepción, Chile.

Becerra, J., C. Flores, J. Mena, P. Aqueveque, J. Alarcón, M. Bittner, et al. 2002. Antifungal and antibacterial activity of diterpenes isolated from Word extractables of Chilean Podocarpaceae. Bol. Soc. Chil. Quim. 47(2):151-157.

Bittner, M., M. Casanueva, C. Aubert, M. Aguilera, V. Hernández, and J. Becerra. 2008. Effects of essential oils from five plant species against the granary weevils Sitophilus zeamais and Acanthoscelides obtectus (Coleoptera). J. Chil. Quim. Soc. 53(1):1444-1448.

Butin, H., y H.L. Peredo. 1986. Hongos parásitos en coníferas de América del Sur con especial referencia a Chile. Biblioteca Mycológica. Vol. 101. 100 p. J. Cramer, Berlin-Stuttgart, Alemania.

Castillo, M. 1992. ¿Y ahora qué? In Muñoz, O. (ed.) Química de la flora de Chile. 341 p. Universidad de Chile, Departamento Técnico de Investigación, Santiago, Chile.

Céspedes, C., A. Uchoa, J. Salazar, F. Perich, and F. Pardo. 2002. Plant growth inhibitory activity of $p$ hidroxiacetofenones and tremetones from Chilean endemic Baccharis species and some analogous: A comparative study. J. Agric. Food Chem. 50:22832292.

Dubey, N.N., K.S. Bhargava, and S.N. Dixit. 1983. Protection of some stored food commodities from fungi by essential oils of Ocimum canum and Citrus medica. Int. J. Trop. Plant. Dis. 1:177-179.

Hoffmann, A., C. Fauga, J. Lastra, y E. Veglozi. 1992. Plantas medicinales de uso común en Chile. 273 p. Ediciones Fundación Claudio Gay, Santiago, Chile.

Gupta, M. 1995. 270 Plantas medicinales iberoamericanas. 617 p. Editorial Convenio Andrés Bello, Santiago, Chile.

Marticorena, C. 1990. Contribución a la estadística de la flora vascular de Chile. Gayana Bot. 47:85-113.

Marticorena, C., y R. Rodríguez. 2001. Flora de Chile. Vol. 2. Winteraceae-Ranunculaceae. 99 p. Universidad de Concepción, Concepción, Chile.

Mishra, A.K., and N.K. Dubey. 1994. Evaluation of some essential oils for their toxicity against fungi causing deterioration of stored food commodities. Appl. Environ. Microbiol. 60:1101-1105.
Mishra, A., N.K. Dubey, S. Singh, and C.M. Chaturvedi. 2002. Biological activities of essential oil of Chenopodium ambrosioides against storage pests and its effect on puberty attainment in Japanese quail. Nat. Acad. Sci. Lett. (India) 25(5-6):176-179.

Mishra, A.K., S.K. Dwivedi, N. Kishore, and N.K. Dubey. 1991. Fungistatic properties of essential oil of Cinnamomum camphora. Int. J. Pharmacogn. 29:259262.

Montes, M.O., L. Muñoz, y T. Wilkomirsky. 2001. Plantas medicinales de uso en Chile. Química y farmacología. 330 p. Editorial Universitaria, Santiago, Chile.

NCCLS. 2000. Performance standards for antimicrobial disk susceptibility test. Approved standard. $7^{\text {th }}$ ed. NCCLS document M2-A7. National Committee for Clinical Laboratory Standards (NCCLS), Wayne, Pennsylvania, USA.

Niemeyer, H.M. 1995. Biologically active compounds from Chilean medicinal plants. p. 137-159. In Arnason, J.T., R. Matta, and J.T. Romeo (eds.) Recent advances in phytochemistry. Vol. 29. Phytochemistry of medicinal plants. Plenum Press, New York, USA.

Oehrens, E., y M. González. 1974. Introducción de Phragmidium violaceum (Schulz) Winter como factor de control biológico de zarzamora Rubus (Rubus constrictus Lef. et M. y R. ulmifolius Schott). Agro Sur 2(1):30-33.

Parra, P., M. González, J.C. Valencia, y J. Faúndez. 2001. Manual para la certificación sanitaria forestal. Manual $\mathrm{N}^{\mathrm{o}} 38.45$ p. FDI-CORFO, Santiago, Chile.

Pérez, R., and J. Ubera. 2006. Fungitoxic activity against phytopathogenic fungi and the chemical composition of Thymus zygis essential oils in South Iberian Península. I Congreso Iberoamericano sobre Seguridad Alimentaria (CIBSA) "de la granja a la mesa, ida y vuelta”, Sevilla, España. 8-10 May 2006. Red Española de Seguridad Alimentaria (SICURA).

Rodríguez, R., y M. Quezada. 2001. Monimiaceae. In Marticorena, C., y R. Rodríguez (eds.) Flora de Chile. Vol. 2. 100 p. Editorial Universidad de Concepción, Concepción, Chile.

Schrickel, S., y M. Bittner. 2001. La salud en nuestras manos. Plantas medicinales en Chile, riqueza natural y científica. 114 p. Editora y Gráfica Lamas, Concepción, Chile.

Shukla, H.S., and S.C. Tripathi. 1987. Antifungal substances in the essential oil of anise (Pimpinella anisum L.). Agric. Biol. Chem. 51:1991-1993.

Solis, C., J. Becerra, C. Flores, J. Robledo, and M. Silva. 2004. Antibacterial and antifungal terpenes from Pilgerodendron uviferum (D. Don) Florin. J. Chil. Quim. Soc. 49(2):157-161. 
Speisky, H., and B.K. Cassels. 1994. Boldo and boldine: an emerging case of natural drug development. Pharmacol. Res. 29:1-12.

Statsoft. 2008. Statistica for Windows (Computer Program Manual). Available at http://www.statsoft. com (Accessed October 2007).

Urzúa, A., and B.K. Cassels. 1982. Additional alkaloids from Laurelia philippiana and L. novae-zelandiae. Phytochemistry 21:773-776.

Vogel, H., I. Razmilic, M. Muñoz, U. Doll, and J.S. Martin. 1999. Studies of genetic variation of essential oil and alkaloid content in boldo (Peumus boldus). Planta Medica 65(19):90-91.
Webster, J., and R. Weber. 2007. Introduction to fungi. $3^{\text {rd }}$ ed. Cambridge University Press, Cambridge, UK.

Woodward, B., and R. De Groot. 1999. Tolerance of Wolfiporia cocos isolates to copper in agar media. Forest Prod. J. 49(4):87-94.

Zin, J.S., y C.R. Weiss. 1998. La salud por medio de las plantas medicinales. 387 p. Ediciones Don Bosco, Santiago, Chile. 